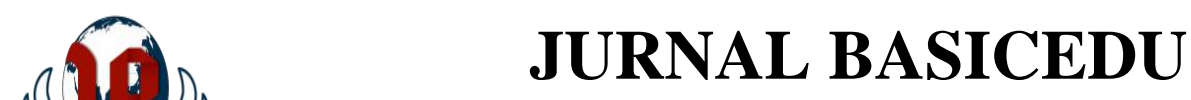

Volume 5 Nomor 2 Tahun 2021 Halaman 1060 - 1066

Research \& Learning in Elementary Education

https://jbasic.org/index.php/basicedu

\title{
An Analysis of The Need for Interactive Multimedia Development Based on Inquiry Training on Science Learning in The Pandemic Period
}

\author{
Uswatun Hasanah $^{1 凶}$, Yufiarti $^{2}$, I Made Astra $^{3}$, Mohamad Syarif Sumantri ${ }^{4}$ \\ Pendidikan Guru Sekolah Dasar, Universitas Negeri Jakarta ${ }^{1,4}$ \\ Psikologi Pendidikan, Universitas Negeri Jakarta ${ }^{2}$ \\ Pendidikan Fisika, Universitas Negeri Jakarta ${ }^{3}$ \\ E-mail: uswatunhasanah@unj.ac.id ${ }^{1}$, yufiarti@unj.ac.id ${ }^{2}$, imadeastra@ gmail.com $^{3}$, syarifsumantri@unj.ac.id ${ }^{4}$
}

\begin{abstract}
Abstrak
Peran media pembelajaran di masa pandemic ini sangatlah penting untuk membantu siswa dalam memahami materi pelajaran. Penelitian ini bertujuan untuk menganalisis kebutuhan siswa terhadap multimedia interaktif berbasis inquiry training pada pembelajaran sains dimasa pandemic. Subjek penelitian adalah siswa sekolah dasar di Kecamatan Setiabudi sebanyak 125 orang yang dipilih secara random sampling. Data dikumpulkan dengan menggunakan teknik wawancara semi terstruktur dan angket kepada beberapa guru dan siswa. Hasil wawancara semi terstruktur menunjukkan bahwa adanya keterbatasan media yang diberikan guru kepada siswa pada pembelajaran sains di masa pandemic ini. Hasil analisis angket kebutuhan siswa menunjukkan bahwa 1) media ajar yang dibutuhkan siswa adalah multimedia interaktif dan 2) materi yang dibutuhkan siswa adalah system pencernaan dan pernapasan pada manusia, serta system reproduksi, dan peredaran darah pada manusia. Penelitiani ini merupakan bagian dari studi awal pengembangan multimedia interaktif berbasis inquiry training pada pembelajaran sains di masa pandemic. Penelitian ini dapat memberikan kontribusi dan solusi bagi para pengajar di masa pandemic untuk selalu berinovasi mengembangkan media yang mampu meningkatkan kualitas pembelajaran.
\end{abstract}

Kata Kunci: multimedia interaktif, inquiry terbimbing, analisis kebutuhan

\begin{abstract}
The role of learning media in this pandemic situation is very important to help students to understand the learning matterials. This study aims to analyze students' needs for inquiry training-based multimedia in science learning during the pandemic. The research subjects were 125 elementary school students in Setiabudi District who were selected by random sampling. Data were collected using interview techniques, semi-structured and questionnaires to several teachers and students. The results of structured interviews show that there are limitations to the media that teachers provide to students in science learning during this pandemic. The results of the student needs analysis show that 1) the material needed by students is interactive multimedia and 2) the material needed by students is the digestive and respiratory systems in humans, as well as management systems and blood circulation in humans. This research is part of an initial study on the development of inquiry-based multimedia training in science learning during a pandemic. This research can provide contributions and solutions for teachers during a pandemic to always innovate to develop media that can improve the quality of learning.
\end{abstract}

Keywords: interactive multimedia, inquiry training, need analysis

Copyright (c) 2021 Uswatun Hasanah, Yufiarti, I Made Astra, Mohamad Syarif Sumantri

Corresponding author :

Email : uswatunhasanah@unj.ac.id

DOI $\quad:$ https://doi.org/10.31004/basicedu.v5i2.881

ISSN 2580-3735 (Media Cetak)

ISSN 2580-1147 (Media Online)

Jurnal Basicedu Vol 5 No 2 Tahun 2021

p-ISSN 2580-3735 e-ISSN 2580-1147 
1061 An Analysis of The Need for Interactive Multimedia Development Based on Inquiry Training on Science Learning in The Pandemic Period - Uswatun Hasanah, Yufiarti, I Made Astra, Mohamad Syarif Sumantri

DOI : https://doi.org/10.31004/basicedu.v5i2.881

\section{INTRODUCTION}

The COVID-19 pandemic has changed the way people live in the world. The Indonesian government has issued many policies related to preventing the spread of Covid 19 which have an impact on the internal and external conditions of the Indonesian government. One of the government policies in the field of education is the home learning policy. Teaching and learning activities that were previously carried out face-to-face must be carried out remotely. In online learning, students become less active in conveying their aspirations and thoughts, so that it can lead to saturating learning. In addition, the limitations of teachers in providing learning cause students do not fully understand the material (Dhawan, 2020; Widodo et al., 2020).

Learning from home is certainly different from learning activities at school, in addition to the existence of learning tools, learning activities are also supported by learning media to make it easier for students to understand the materials. One of them is in learning science. In these subjects, there is material that is very difficult to explain if taught in distance learning. Some of these include the human digestive system, respiratory system, and circulatory system. This causes students do not understand optimally if taught abstractly. The presence of learning media can be used as a communication tool in the science learning process, it is said that because in the learning process there is a process of delivering messages from educators to students (Booth, 2016; Kim, 2019; Yosso, 2020). Learning media is also defined as one of the external factors that influence the success of learning activities, in general the benefits of media. Media provides opportunities for teachers to focus their duties on individual guidance and counseling in learning activities (Rihatno \& Nuraini, 2017; Wuryan \& Yufiarti, 2017). Which indirectly, the use of media in the learning process increases the effectiveness of the role of teachers to students.

As knowledge and technology advance, the media has developed into multimedia. As it means, multi is more than one, multimedia is a combination of more than one media that can facilitate the learning process. Multimedia is able to facilitate students with various learning styles (auditory, visual, kinesthetic) (Huang, 2019; Shangguan, 2020; $\mathrm{Xu}, 2016$ ). In addition, the use of multimedia is more effective because it can present information that can be seen, heard and carried out. In this case the researcher will develop an interactive multimedia in science learning during this pandemic. Interactive multimedia is not linear, which means students can choose according to the menu offered. In addition, interactive multimedia offers feedback that can increase learning motivation (Anisimova, 2020). Thus, interactive multimedia is multimedia that is suitable to use as a medium in learning, one of which is science learning. Interactive multimedia is a media that is equipped with a control device that can be operated by students, resulting in interaction and direct involvement of students in learning (Kang, 2018).

In this study, the researchers developed an interactive multimedia in science learning for elementary school students. Some relevant research (Bron \& Barrio, 2019; Krajka, 2016; Leonard, 2017) shows that the existence of multimedia that has been implemented in elementary schools in the form of presentation slides, instructional videos, and animation videos. In this study, researchers will create an interactive multimedia application in which there are text, graphics, audio, video, and animation and interactivity. Interactivity is also a part of the elements needed to complete the interactive communication process in using multimedia. Each of these elements has their respective roles in creating interesting and memorable information. Interactivity is not a medium. Interactivity is the design behind a multimedia program. Interactivity allows a person to access various forms of media or channels in a multimedia program so that the program is more meaningful and more satisfying for users. Interactivity is also called interface design or human factor design (Borodzhieva, 2020; Sukardjo, 2018). In addition, interactive multimedia that will be developed is integrated with the inquiry training approach where students are guided in exploring, observing, explaining a phenomenon to solving a problem 
1062 An Analysis of The Need for Interactive Multimedia Development Based on Inquiry Training on Science Learning in The Pandemic Period - Uswatun Hasanah, Yufiarti, I Made Astra, Mohamad Syarif Sumantri

DOI : https://doi.org/10.31004/basicedu.v5i2.881

(Ellis \& Bliuc, 2019; Siburian et al., 2019). Thus, the existence of interactive multimedia based on inquiry training will increase activeness and facilitate students to understand the lesson.

Based on the analysis of some of the above studies, the researchers ares interested in conducting a need analysis study related to interactive multimedia in elementary schools. This research seems to show something that is different from the previous one, the research subjects are elementary school students and the research method used was descriptive qualitative and the sample population were in the Setiabudi area which is certainly different from its socio-economic and emotional background with previous research. This research is important to study because it is a preliminary study of further development research.

\section{METHOD}

This research is a qualitative descriptive study with a survey method which was conducted from February to March for elementary school students. The population was all fifth-grade of elementary school students in the Setiabudi district. The sample was randomly selected as many as 125 students. Technique of data collection used semi-structured interviews and questionnaires. The interview technique used a video call application to get additional or complementary data. Researchers conducted interviews with several teachers to obtain additional data sources. The questionnaire was distributed online via google form. These questionnaires and interviews contain questions that aim to obtain data about the learning media provided during the pandemic, the teaching media needs desired by elementary school students, and what material is difficult to understand during online learning in this pandemic. The research data were analyzed descriptive qualitatively.

\section{RESULT AND DISCUSSION}

Based on the results of semi-structured interviews with teachers, data is obtained as listed in table 1.The data from the questionnaire results that were distributed to 125 students related to the learning media provided during the pandemic are shown in table 1, while the questionnaire results data related to the teaching media needs desired by elementary school students shown in table 2 . The data from the questionnaire results related to material that was difficult to understand in online learning during this pandemic is shown in table 3 .

\section{Table 1}

\section{Interview Results}

\begin{tabular}{|l|l|}
\hline No. & \multicolumn{1}{c|}{ Interview result } \\
\hline 1 & $\begin{array}{l}\text { During the pandemic, } 87 \% \text { of teachers only delivered structured assignments through WhatsApp } \\
\text { groups, while others taught with the help of the google classroom application and zoom meetings. }\end{array}$ \\
\hline 2 & $\begin{array}{l}\text { The learning media that teachers provide to students in science learning are limited to power points, } \\
\text { videos downloaded from YouTube, educational radio, and television broadcasts related to science } \\
\text { learning. }\end{array}$ \\
\hline 3 & Many students are saturated and passive in this online learning \\
\hline 4 & The teacher is transfixed in delivering teaching materials from books provided by the government. \\
\hline 5 & There are students who find it difficult to understand abstract science materials \\
\hline 6 & The difficulty of teachers directly accessing online media \\
\hline
\end{tabular}



Sumantri

Table 2

Instructional media provided during the pandemic

\begin{tabular}{|l|l|l|}
\hline No. & Media & Amount (\%) \\
\hline 1 & Textbooks for lessons & $22.4 \%$ \\
\hline 2 & YouTube videos & $27,2 \%$ \\
\hline 3 & Educational Radio & $8.8 \%$ \\
\hline 4 & Television & $10.4 \%$ \\
\hline 5 & Power point & $31,2 \%$ \\
\hline
\end{tabular}

Table 3

Types of material that are difficult to understand during online learning during this pandemic

\begin{tabular}{|l|l|}
\hline No. & \multicolumn{1}{|c|}{ Science Learning Materials } \\
\hline 1 & Human Digestive System \\
\hline 2 & Human Respiratory System \\
\hline 3 & Blood Circulation in Humans \\
\hline 4 & Reproductive System in Humans \\
\hline
\end{tabular}

Based on the results of structured interviews with several teachers, it shows that during this pandemic, $87 \%$ of teachers only delivered structured assignments through the WhatsApp group, while others taught assisted by the google classroom and zoom meeting applications. This fact illustrates that the online learning process at home is only limited to doing structured assignments from the teachers. Of course, if learning is not varied, it will result in boredom and burdens for elementary school students. This condition can be caused by several factors, one of which is the limitations of teachers in creating communicative teaching media to students and a lack of initiative in developing interactive learning. This factor can be proven from the media that teacher applies to students in science learning as limited as PowerPoint, videos downloaded from YouTube, educational radio, and television broadcasts related to science learning. Teachers are still fixated on the concept of material contained in textbooks. In essence, these textbooks are sufficient to be used as a reference only, the rest can be developed based on the teacher's own innovation. With the online learning model that is carried out, it causes student learning outcomes not optimal. Many of them have difficulty understanding the subject matter. As a result, the learning that is carried out becomes meaningless. With the online learning model that is carried out it causes the unoptimality of student learning outcomes. Many of them have difficulty in understanding the learning matterials. As a result, the learning that is carried out becomes meaningless.

Essentially, media development is one of the obligations for teachers to improve their existence as professional educators. Basically, learning media is anything that can be used to transmit messages from sender to receiver so that it can stimulate students' thoughts, feelings, attention, and interests in such a way that the learning process occurs. In accordance with its function, learning media is basically to improve the quality of teaching and learning. Therefore, in the teaching and learning process in schools, learning media has very important benefits (Fahrurrozi et al., 2019; Muflihah \& Aziz, 2018; Rahmat, 2019).

The learning media provided during the pandemic were textbooks, YouTube videos, educational radio, television, and power points. In this case, the power point slide shows is in the highest score (31.2\%), then followed by YouTube videos (27.2\%), textbooks (22.4\%), television (10.4\%), and radio education (8.8\%). The results showed that most of the teachers gave power points in the form of presentation slides to students. This media is quite good but has limitations, among others, the lack of an element of student interactivity towards the media. Based on research (Abu-Arqoub, 2020; Imole, 2015) show that people remember 20\% of what they see, $40 \%$ of what they see and hear, but about $75 \%$ of what they see and hear and do simultaneously. This is illustrated in the cone of Edgar Dale's experience. This statement shows that students will better understand and 
1064 An Analysis of The Need for Interactive Multimedia Development Based on Inquiry Training on Science Learning in The Pandemic Period - Uswatun Hasanah, Yufiarti, I Made Astra, Mohamad Syarif Sumantri

DOI : https://doi.org/10.31004/basicedu.v5i2.881

interpret the lesson if it is assisted by interactive media. This multimedia combines text, graphics, audio, video, and animation and interactivity so that learning will be more fun and contextual (Anisimova, 2020). Multimedia can also facilitate all learning styles, both auditory, kinesthetic, and visual (Huang, 2019; Shangguan, 2020; Wuryan \& Yufiarti, 2017; Xu, 2016). Thus, interactive multimedia can be a solution to existing problems.

Then the next table explains what types of material are difficult to understand during a pandemic. Most of them answer the material of the digestive and respiratory systems in humans, the reproductive system, and the blood circulation. All this material is intended so that we can know how the processes or uses of our body organs are as humans, so that we can understand our bodies as a whole and treat our bodies well. This material is indeed abstract, so it requires media that is able to provide students' optimal understanding.

In the development of learning media, we really have to pay attention to several things. The main principle of selecting instructional media is the effectiveness of learning media in achieving learning objectives and its effectiveness in helping students understand the learning material to be presented. We have to consider whether a learning media to be used is more effective when compared to other media. Learning media must also be selected based on the principles of students' level of thinking. The third principle that must be considered in selecting media in classroom learning is interactivity and flexibility (Alexander et al., 2016; Booth, 2016; Puspita \& Setyowati, 2015). The learning media chosen by the teacher for teaching and learning activities in their class should have good interactivity and flexibility. The learning media is said to have good flexibility if it can be used in various situations. Thus, some of these things are used as a consideration for researchers in developing learning media.

From the results of the needs analysis, researchers will develop inquiry-based interactive multimedia to increase students' activeness and understanding. The multimedia development that will be carried out refers to the 4-D model development procedure developed by Thiagarajan which consists of Define, Design, Develop, Disseminate (Kurniawan \& Dewi, 2017; Rachmadtullah, 2018). The reason for choosing the 4-D model is based on the procedures used in this model to provide opportunities for textbook makers to revise (evaluate) continuously at each stage that is passed so that it can produce better media. The 4-D development model is also simple but systematic in implementing it. The limitations of multimedia that will be developed are the availability of mobile phone facilities for students and their ability to organize the hyperlinks contained therein. Therefore, the involvement of teachers and parents is very important in guiding students to carry out learning at home (Lammert et al., 2018; Patrikakou Eva N.1, 2016).

\section{CONCLUSION}

Based on the data from the research and discussion that has been done, it can be concluded that the obstacles faced in learning science are the absence of interactive media that can provide understanding and are interesting in delivering science material, especially material that is abstract. This research is a preliminary study of further development research. This study can provide input for further researchers to develop suitable media to be given to students during this pandemic so that the resulting learning will be fun and of quality. In addition, the results of this study can provide contributions and solutions for teachers in this pandemic to always innovate in developing media that can increase students' understanding. Media products that will be developed by researchers will also be useful as new media that have an element of interactivity integrated in inquiry training so that they can be used as references and input for the advancement of science in the future. 
1065 An Analysis of The Need for Interactive Multimedia Development Based on Inquiry Training on Science Learning in The Pandemic Period - Uswatun Hasanah, Yufiarti, I Made Astra, Mohamad Syarif Sumantri

DOI : https://doi.org/10.31004/basicedu.v5i2.881

\section{REFERENCES}

Abu-Arqoub, M. (2020). Interactive Multimedia-Based Educational System for Children Using Interactive Book with Augmented Reality. Journal of Computer Science, 15(11), 1648-1658. https://doi.org/10.3844/jcssp.2019.1648.1658

Alexander, B., Adams Becker, S., \& Cummins, M. (2016). An NMC Horizon Project Strategic Brief. 3(October). http://cdn.nmc.org/media/2016-nmc-horizon-strategic-brief-digital-literacy.pdf

Anisimova, E. S. (2020). Digital literacy of future preschool teachers. Journal of Social Studies Education Research, 11(1), 230-253.

Booth, P. (2016). Board, game, and media: Interactive board games as multimedia convergence. Convergence, 22(6), 647-660. https://doi.org/10.1177/1354856514561828

Borodzhieva, A. N. (2020). Designing an interactive multimedia application for the course "communication circuits." In 2020 43rd International Convention on Information, Communication and Electronic Technology, MIPRO $2020 \quad$ - $\quad$ Proceedings (pp. 1561-1566). https://doi.org/10.23919/MIPRO48935.2020.9245086

Bron, M., \& Barrio, M. G. (2019). Project-Based Learning for Teaching Transmedia Communication. Journal of Problem Based Learning in Higher Education, 7(1), 141-151. https://doi.org/10.5278/ojs.jpblhe.v7i1.2405

Dhawan, S. (2020). Online Learning: A Panacea in the Time of COVID-19 Crisis. Journal of Educational Technology Systems, 49(1), 5-22. https://doi.org/10.1177/0047239520934018

Ellis, R. A., \& Bliuc, A. M. (2019). Exploring new elements of the student approaches to learning framework: The role of online learning technologies in student learning. Active Learning in Higher Education, 20(1), 11-24. https://doi.org/10.1177/1469787417721384

Fahrurrozi, Hasanah, U., \& Dewi, R. S. (2019). Integrated Learning Design Based on Google Classroom to Improve Student Digital Literacy. 2019 5th International Conference on Education and Technology, ICET 2019, 108-111. https://doi.org/10.1109/ICET48172.2019.8987219

Huang, H. (2019). Applied to Mobile Multimedia Intelligent Speech System Interactive Topic Guiding Model. IEEE Access, 7, 182348-182356. https://doi.org/10.1109/ACCESS.2019.2959906

Imole, O. (2015). Call admission control for multimedia connections in interactive satellite networks. In IEEE AFRICON Conference (Vol. 2015). https://doi.org/10.1109/AFRCON.2015.7332056

Kang, Z. (2018). Multimodal perception study on virtual 3D curved textures with vision and touch for interactive multimedia systems. Multimedia Tools and Applications, 77(2), 2209-2223. https://doi.org/10.1007/s11042-017-4392-8

Kim, K. T. (2019). The structural relationship among digital literacy, learning strategies, and core competencies among south korean college students. Educational Sciences: Theory and Practice, 19(2), 3-21. https://doi.org/10.12738/estp.2019.2.001

Krajka, J. (2016). CLIL instruction in online interactive multimedia: A case study of Polish middle school learners of English. International Journal of Continuing Engineering Education and Life-Long Learning, 26(2), 168-182. https://doi.org/10.1504/IJCEELL.2016.076013

Kurniawan, D., \& Dewi, S. V. (2017). Pengembangan Perangkat Pembelajaran dengan Media Screencast- OMatic Mata Kuliah Kalkulus 2 Menggunakan Model 4-D Thiagarajan. Jurnal Siliwangi, 3(1), 214-219.

Lammert, J., Moore, H., \& Bitterman, A. (2018). IDC Parent Involvement Toolkit Making the Most of Parent Involvement Data: Improving Quality and Enhancing Understanding. Westat, September, 1-103.

Leonard, S. (2017). Model-based development of interactive multimedia system. In 2017 3rd IEEE International Conference on Cybernetics, CYBCONF 2017 - Proceedings. 
1066 An Analysis of The Need for Interactive Multimedia Development Based on Inquiry Training on Science Learning in The Pandemic Period - Uswatun Hasanah, Yufiarti, I Made Astra, Mohamad Syarif Sumantri

DOI : https://doi.org/10.31004/basicedu.v5i2.881

https://doi.org/10.1109/CYBConf.2017.7985791

Muflihah, M., \& Aziz, H. (2018). Developing Interactive Multimedia CD-based Teaching Materials for Teaching Arabic Skill at Arabic Education Department of Islamic State University Sunan Ampel Surabaya. Dinamika Ilmu, 18(2), 195-210. https://doi.org/10.21093/di.v18i2.1158

Patrikakou Eva N.1, E. ed. (2016). Parent Involvement, Technology, and Media: Now What? School Community Journal, 26(2), 9-24. http://search.ebscohost.com/login.aspx?direct=true\&db=eft\&AN=120454446\&site=ehost-live

Puspita, D., \& Setyowati, E. (2015). Fashion and Fashion Education Journal. Fashion and Fashion Education Journal, 4(1), 1-6.

Rachmadtullah, R. (2018). Development of computer-based interactive multimedia: Study on learning in elementary education. International Journal of Engineering and Technology(UAE), 7(4), 2035-2038. https://doi.org/10.14419/ijet.v7i4.16384

Rahmat, H. (2019). Development of learning media based on interactive multimedia in mathematics learning for class viii junior high school in Indonesia. International Journal of Scientific and Technology Research, $8(12)$, 2592-2594. https://www.scopus.com/inward/record.uri?partnerID=HzOxMe3b\&scp=85077520605\&origin=inward

Rihatno, T., \& Nuraini, S. (2017). BRAIN-BASED TEACHING FOR UNIVERSITY IN DIGITAL ERA : 5(2), $215-222$.

Shangguan, C. (2020). More Attractive or More Interactive? The Effects of Multi-Leveled Emotional Design on Middle School Students' Multimedia Learning. Frontiers in Psychology, 10. https://doi.org/10.3389/fpsyg.2019.03065

Siburian, J., Corebima, A. D., Ibrohim, \& Saptasari, M. (2019). The correlation between critical and creative thinking skills on cognitive learning results. Eurasian Journal of Educational Research, 2019(81), 99114. https://doi.org/10.14689/ejer.2019.81.6

Sukardjo, M. (2018). Measurement of Usability for Multimedia Interactive Learning Based on Website in Mathematics for SMK. In IOP Conference Series: Materials Science and Engineering (Vol. 336, Issue 1). https://doi.org/10.1088/1757-899X/336/1/012032

Widodo, A., Nursaptini, N., Novitasari, S., Sutisna, D., \& Umar, U. (2020). From face-to-face learning to web base learning: How are student readiness? Premiere Educandum: Jurnal Pendidikan Dasar Dan Pembelajaran, 10(2), 149. https://doi.org/10.25273/pe.v10i2.6801

Wuryan, \& Yufiarti. (2017). The effect of teaching methods and learning styles on capabilities of writing essays on elementary schools students in East Jakarta. Educational Research and Reviews, 12(12), 635-642. https://doi.org/10.5897/err2017.3187

$\mathrm{Xu}, \mathrm{Z}$. (2016). An interactive visual user interface model for multimedia open annotation tools. International Journal of Multimedia and Ubiquitous Engineering, 11(7), 103-118. https://doi.org/10.14257/ijmue.2016.11.7.11

Yosso, T. J. (2020). Critical race media literacy for these urgent times. International Journal of Multicultural Education, 22(2), 5-13. https://doi.org/10.18251/ijme.v22i2.2685 